Volume 3 Nomor 2, Juli-Desember 2019: hlm. 77-84.

Magister Ilmu Hukum, Fakultas Hukum, Universitas Lampung,

Bandar Lampung, Lampung, Indonesia.

E-ISSN: 2598-3105 P-ISSN: 2723-2581

http://jurnal.fh.unila.ac.id/index.php/cepalo

(․) $(\odot)$ CEPALO

\title{
IMPLIKASI OVERCAPACITY TERHADAP LEMBAGA PEMASYARAKATAN DI INDONESIA
}

\section{IMPLICATIONS OF OVERCAPACITY FOR CORRECTIONAL INSTITUTIONS IN INDONESIA}

\author{
Ilham Panunggal Jati Darwin \\ Magister Hukum Universitas Indonesia \\ ilhampanunggal.ui2018@gmail.com
}

\begin{abstract}
Abstrak
Overcapacity sederhananya dapat disebabkan oleh tingginya jumlah napi yang masuk yang tak berbanding lurus dengan kapasitas Lembaga pemasyarakatan, besaran jumlah napi yang masuk dengan jumlah narapidana yang keluar amat tak berimbang, jumlah narapidana baru jauh melebihi jumlah masa pidana penjaranya dan jumlah narapidana yang keluar, permasalahan lembaga pemasyarakatan yang penuh sesak telah menjadi permasalahan yang kian berlarut-larut serta menimbulkan banyak dampak baik terhadap para narapidana maupun negara, Berdasarkan permasalahan tersebut penelitian ini bertujuan untuk membahas bagaimanakah implikasi overcapacity terhadap Lembaga pemasyarakatan di indonesia, dengan menggunakan metode penelitian kuantitatif yakni dengan studi kepustakaan,di tarik kesimpulan bahwa permasalahan Overcapacity disebabkan oleh beberapa faktor, baik permasalahan Lembaga Pemasyarakatan yang sudah tidak memadai hingga masih minimnya pidana yang non-penjara, serta pandangan stigma "penjahat" dari masyarakat yang turut membentuk seseorang untuk kembali menjadi residivice, kemudian overcapacity berdampak pada kesehatan fisik dan mental para narapidana, tercatat banyak narapidana yang meninggal baik faktor penyakit maupun bunuh diri, selain itu juga berdampak besar terhadap anggaran yang kian meningkat setiap tahunnya.
\end{abstract}

Kata Kunci: Lapas; Tahanan; Kapasitas Lapas; Overcapacity.

\begin{abstract}
Overcapacity can simply be influenced by the number of prisoners who enter that is not directly proportional to the prison capacity, the number of prisoners who enter the innumerable amount of prisoners who come out, the number of prisoners in prison that is complicated becomes increasingly protracted, which also affects both prisoners and the countries, Based on this issue, this paper aims to discuss how the implications of overcapacity to correctional institutions in Indonesia, using quantitative research methods with literature studies, conclude due to the problem of overcapacity by several factors, both the Penal Institution debate which is inadequate to the minimum prison. People, as well stigmatised the "villain" can make prisoners return as recidivism, then how the overcapacity impact on the health and mentality of inmates, Noted many prisoners who ended with both disease and suicide, while also increasing broad for the sake of a budget that is increasing every year.
\end{abstract}

Keywords: Correctional Institution, Prisoners, Life Quality, Overcapacity.

Cara Mengutip (How to Cite): Ilham Panunggal Jati Darwin, "Implikasi Overcapacity Terhadap Lembaga Pemasyarakatan di Indonesia”, Jurnal Cepalo, 3 (2), (2019): 77-84.

DOI: https://doi.org/10.25041/cepalo.v3no2.1847

\section{A. Pendahuluan}

Gagasan mengurung seseorang serta memenjarakan saat ini lebih dikenal dengan konsep gagasan, ide untuk menempatkan seseorang kedalam sebuah tempat pengasingan dengan maksud agar ia tidak melakukan 
segala perbuatan jahat serta kejahatan-kejahatannya, konsep ini telah dikenal sejak abad ke lima sebelum masehi. Pada awalnya, sekitar tahun 1670 belum mengenal konsep hukuman kurungan, namun dikenal sebuah pemidanaan dengan melakukan sandra terhadap pelaku dengan tebusan sejumlah uang serta diberikan potongan atau penggantian bentuk hukuman yang dijatuhkan kepada pelaku. Negara inggris sekitar tahun 1200-1400 saat zaman abad pertengahan telah muncul konsep hukuman dengan mengurung pada rumah ibadah (cruch), dengan menempatkan nya pada bilik di dalam cruch yang muncul di kota Bridwedell (pada sekitar abad 16) kemudian muncul lagi konsep hukuman kurungan dengan melakukan pekerjaan tertentu seperti yang tercatat didalam Act of 1576 dan Act of 1609 serta pidana kurungan seperti di dalam Act of 1711. Howard Jones menjelaskan, semenjak kerajaan Mesir sekitar tahun 2000 (SM) sudah di kenali konsep menahan seseorang dalam sebuah tempat dalam proses proses peradilan, juga dikenal demi menahan pelaku demi proses peradilan lain seperti di romawi pada jaman kekuasaan raja Justianus abad 5 (SM).

Penghukuman dengan memberikan dilihat sebagai upaya untuk memperbaiki akhlak sang pelaku dan dianggap hukuman yang manusiawi, kemudian dikenal dua jenis hukuman yaitu saat malam dikurung sendiri dan saat siang bekerja bersama-sama. ${ }^{1}$ Saat menjalani hukuman kerja paksa terpidana tidak diperbolehkan untuk saling berbincang dan mengobrol tentang permasalahan yang berhubungan dengan pekerjaannya. Maka sebab itu maka sistem ini disebut juga dengan "Silent Sistem". Masa-Masa hukuman memperkerjakan tahanan ini berjalan semenjak zaman ke-19 atau akuratnya dimulai sejak tahun 1872 sampai tahun 1905. Dicirikan atas munculnya dua tipe hukum pidana; satu yakni hukum pidana yang spesifik bagi masyarakat Indonesia serta kedua, pidana spesifik bagi masyarakat Eropa ${ }^{2}$. Untuk Masyarakat pribumi serta golongan Timur Asing diberlakukan Kitab Undang-undang Hukum Pidana khusus, yaitu kitab "Wetboek van Strafrecht voor de Inlanders in Nederlandsch Indie", bila diartikan maka berarti Kitab Undang-undang Hukum Pidana bagi masyarakat pribumi yang berada dalam Hindia Belanda. Masyarakat pribumi disebut sebagai masyarakat "Inlanders". Saat masa tersebut konsep pemidanaan dengan memberikan bekerja adalah hukuman yang kerapkali diberikan kepada "inlanders". Jangka waktu berapa durasi hukuman ini amat beragam dan berbeda-beda dapat sepanjang hidupnya, namun juga dapat di jatuhkan selama sehari. Penjara merupakan gambaran masyarakat jajahan saat itu. "Ada orang-orang penjajah yang penuh hak dan ada masyarakat terjajah yang penuh wajib," seperti yang ditulis Koesnoen dalam Politik Pendjara Nasional ${ }^{3}$. Asal-usul munculnya lapas di negara Indonesia ini sangat terkait dengan kisah pembentukan negara indonesia, yang mengalami saat-saat berat pada saat Belanda dan Jepang melakukan penjajahan. Berbagai zaman telah berlalu, banyak kisah disetiap zaman yang telah tercatat yang kemudian berbagai zaman tersebut memiliki kisahnya tersendiri. ${ }^{4}$

Selepas negara Indonesia merdeka gagasan untuk mengurung seseorang dan penjara tidak juga menerapkan konsep pengayoman yang baik, penjara atau lapas justru saat ini beralih fungsi sebagai sebuah lokasi "penampungan" untuk pelaku tindak pidana, dan sudah menjadi fakta bahwa pada saat ini sebagian besar penjara atau lembaga pemasyarakatan serta rumah tahanan negara (rutan) di Indonesia mengalami overcapacity yang sangat parah. Keadaan demikian kian memburuk hingga kini, hal tersebut dicipu oleh banyak sebab Kepala Sub Direktorat Komunikasi Direktorat Jenderal Pemasyarakatan (Ditjen PAS) Kementerian Hukum dan HAM, Akbar Hadi Prabowo. Menjabarkan setidaknya terdapat empat faktor terjadinya overcapacity Pertama, faktor banyaknya kejahatan yang terjadi setiap hari. Kedua, kurangnya proses (pre-trial detention) atau penahanan dalam Lembaga kepolisian dan kejaksaan. Ketiga, faktor banyaknya napi dan tahanan yang tidak lagi dapat ditampung oleh kapasitas Lembaga pemasyarakatan dan rumah tahanan. Keempat, hal tersebut juga di dukung oleh oleh berlakunya Peraturan Pemerintah (PP) 99 Tahun 2012. PP itu dirasa sangat menyulitkan napi untuk dapat mengajukan potongan masa tahanan atau pembebasan bersyarat. $^{5}$

Tabel kantor wilayah cabang Lembaga pemasyarakatan di 33 provinsi yang mengalami Overcapacity sejak tahun 2017 hingga 2019

\footnotetext{
${ }^{1}$ Departemen Kehakiman Rl, Dari Kepenjaraan Kepemasyarakatan,Direktorat Jendral Pemasyarakatan, Jakarta: Departemen Kehakiman Rl, (1983), hlm. 11.

${ }^{2}$ Petrusirawan Panjaitan, Pidana Penjara Mau Kemana, Jakarta: Ind-hill CO, (2007), hlm. 47

${ }^{3}$ Hendaru Tri Hanggoro. Cerita Dari balik Jeruji Besi. Tersedia Online di https://historia.id/politik/articles/cerita-dari-balik-jerujibesi-vqjAB, dikutip pada tanggal 05 Mei 2019 pada pukul 23:41 WIB.

${ }^{4}$ Romli Atmasasmita, Dari Pemendjaraan ke Pembinaan Narapidana, Bandung: Alumni, hlm. 49.

5 Mihardi. Ditjen Pas Ungkap Empat Penyebab Lapas Kelebihan Kapasitas. Tersedia Onile pada https://nasional.sindonews.com/read/1161936/13/ditjen-pas-ungkap-empat-penyebab-lapas-kelebihan-kapasitas-1481310610, dikutip pada Tanggal 19 Februari 2019, Pukul 08.32 WIB.
} 


\begin{tabular}{|c|c|c|c|c|c|c|c|c|c|c|c|c|c|c|c|c|c|c|c|c|c|}
\hline \multirow{2}{*}{\multicolumn{14}{|c|}{ 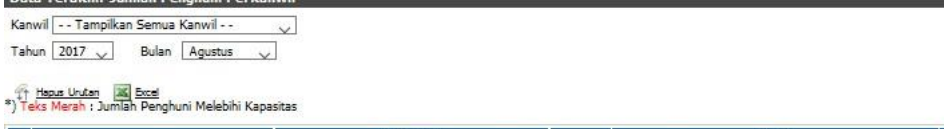 }} & \multicolumn{8}{|c|}{ 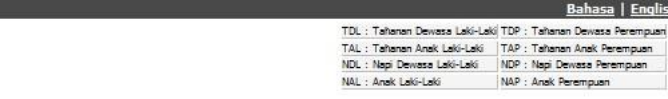 } \\
\hline & & & & & & & & & & & & & & & & & & & & & \\
\hline \multirow[b]{2}{*}{ Mo } & \multirow[b]{2}{*}{ Kanwil } & \multicolumn{5}{|c|}{ Tahanan } & \multirow[b]{2}{*}{ Iotal } & \multicolumn{6}{|c|}{ Napi } & \multirow[b]{2}{*}{ Iotal } & \multirow{2}{*}{\begin{tabular}{|c|}
$\frac{\text { Tahanan }}{\frac{8}{\text { Napi }}}$ \\
$\underline{\text { Napis }}$
\end{tabular}} & \multirow[b]{2}{*}{ Kapasitas } & \multirow{2}{*}{\begin{tabular}{c|}
$\begin{array}{c}\% \\
\text { Over } \\
\text { Kapasitas }\end{array}$ \\
\end{tabular}} & \multicolumn{2}{|c|}{$\begin{array}{l}\text { UPT } \\
\end{array}$} & \multirow[b]{2}{*}{ Total } & \multirow[b]{2}{*}{ Created Date } \\
\hline & & DL & $\underline{\mathrm{DP}}$ & ID & AL $A$ AF & IA & & DL & $\underline{\text { DP }}$ & $\underline{\text { ID }}$ & $\begin{array}{ll}\text { AL } & \text { AP } \\
\end{array}$ & $\begin{array}{lll}A P & \text { If } \\
\end{array}$ & TA & & & & & \begin{tabular}{l|} 
Melebihi \\
Kapasitas
\end{tabular} & \begin{tabular}{|c|} 
Tidak Melebihi \\
Kapasitas
\end{tabular} & & \\
\hline 1 & KANWIL ACEH & 2,107 & 117 & 2,224 & 11 & 112 & 2,236 & 4,684 & 203 & 4,887 & 54 & 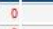 & 54 & 4,941 & 7,177 & 4,090 & 75 & 18 & & 26 & $\frac{16}{62017-08-31 \quad 08: 03: 40}$ \\
\hline 2 & KANWLL BALI & 878 & 74 & 952 & & 18 & 970 & 1,511 & 176 & 1,687 & 200 & 0 & 20 & 1,707 & 2,677 & 1.496 & 79 & 8 & & 11 & $12017-00-3108: 13: 10$ \\
\hline 3 & KANWLL BANGKA BEUTUNG & 504 & 39 & 543 & 9 & 9 & 552 & 1,471 & 75 & 1,546 & 15 & 0 & 15 & 1,561 & 2,113 & 1,348 & 57 & 5 & & & $7 \quad 2017-08-3108: 23: 35$ \\
\hline 4 & KANWIL EANTEN & 2,799 & 128 & 2,927 & 25 & 25 & 2,952 & 4,676 & 563 & 5,239 & 62 & 3 & 65 & 5,304 & 8.256 & 5,137 & 61 & 9 & & 11 & $12017-08-3108: 25: 13$ \\
\hline 5 & KANWTL BENGKULU & 575 & 40 & 615 & 20 & 20 & 635 & 1.514 & 69 & 1,583 & 96 & 4 & 100 & 1,683 & 2.318 & 1,562 & 48 & 5 & & 7 & 7 2017-08-31 08:00:06 \\
\hline 6 & KANWIL D.1. YOGYAKARTA & 499 & 29 & 528 & 3 & 3 & 531 & 951 & 88 & 1,039 & 30 & 1 & 31 & 1,070 & 1,601 & 1,975 & 0 & 4 & & 9 & 9 2017-08-31 08:04:38 \\
\hline 7 & $\overline{\text { KANWILL DKI JAKARTA }}$ & 6,358 & 549 & 6,907 & 45 & 46 & 6,953 & 8,884 & 538 & 9,422 & 24 & 1 & $25^{\circ}$ & 9,447 & 16,400 & 5,851 & 180 & 8 & & 9 & $92017-08-3108: 19: 30$ \\
\hline & KANWIL GORONTALO & 137 & 21 & 158 & 1 & 1 & 159 & 596 & 52 & 648 & 8 & 0 & 8 & 656 & 815 & 767 & 6 & 1 & & & 5 2017-08-31 08:45:20 \\
\hline & KANWIL JAMBI & 494 & 51 & 545 & 8 & 8 & 553 & 2,954 & 182 & 3,136 & 69 & 1 & 70 & 3,206 & 3.759 & 2,090 & 80 & 9 & & 10 & Belum Lapor \\
\hline & KANWVLL JAWA BARAT & 5,350 & 195 & 5,545 & 58 & 59 & 5,604 & 15,830 & 653 & 16,483 & 220 & 3 & 223 & 16,706 & 22,310 & 15,679 & 43 & 25 & & 32 & $12 \quad 2017-00-3108: 19: 41$ \\
\hline & KANWIL JAWA TENGAH & 3,312 & 157 & 3,469 & 49 & 50 & 3,519 & 7,786 & 461 & 8.247 & 94 & 0 & 94 & 8,341 & 11.860 & 8,197 & 45 & 35 & & 44 & 4 2017-08-31 08:47:46 \\
\hline 12 & KANWIL JAWA TIMUR & 8,061 & 494 & 8,555 & 1244 & 128 & 8,683 & $13,510^{\circ}$ & 706 & 14,216 & 193 & 7 & 200 & 14,416 & 23,099 & 12,381 & 87 & 32 & & 38 & 8 2017-00-31 08:57:09 \\
\hline & KANWLL KALIMANTAN BARAT & 1,376 & 87 & 1,463 & 30 & 31 & 1,494 & 2,738 & 181 & 2,919 & 71 & 1 & 72 & 2.991 & 4,485 & 2,529 & $\pi$ & 9 & & 13 & $32017-00-31$ 08:03:21 \\
\hline & KANWTL KALIMANTAN SELATAN & 1.767 & 144 & 1,911 & 230 & 23 & 1,934 & 6,151 & 538 & 6,689 & 70 & 6 & 76 & 6,765 & 8.699 & 3,447 & 152 & 13 & & 14 & 4 2017-08-31 08:00:14 \\
\hline & KANWZL KALIMANTAN TENGAH & 918 & 62 & 980 & & 5 & & 2,529 & 233 & 2,762 & 22 & 2 & 24 & 2,786 & 3,771 & 2,344 & 74 & 7 & & 11 & 1 2017-08-31 08:20:12 \\
\hline 16 & KANWLL KALIMANTAN TIMUR & 2,476 & 190 & 2,666 & $28=$ & 30 & 2,696 & 6,944 & 527 & 7,471 & 88 & 3 & 91 & 7,562 & 10,258 & 3,586 & 222 & 11 & & 11 & 1 Beum Lapor \\
\hline 17 & KANWIIL KEPULAUAN RIAU & 999 & 61 & 1,060 & 330 & 33 & 1,093 & 3,056 & 201 & 3,257 & 53 & 0 & 53 & 3,310 & 4,403 & 2,505 & 76 & 7 & & 9 & 2017-08-31 08:00:45 \\
\hline & KANWILLAMPUNG & 2,495 & 95 & 2,590 & 72 & 73 & 2,663 & $4,545^{\circ}-10$ & 196 & 4,741 & 209 & 3 & 212 & 4,953 & 7,616 & 5,348 & 42 & 14 & & 16 & 6 2017-00-31 08:17:09 \\
\hline & KANWTL MALUKU & 274 & 22 & 296 & 30 & 3 & 299 & 713 & 43 & 756 & 14 & 0 & 14 & 770 & 1,069 & 1,315 & 0 & 4 & & & 5 2017-00-31 08:19:48 \\
\hline & KANWTL MALUKU UTARA & 256 & 27 & 283 & 21 & 3 & 286 & 647 & 24 & 671 & 6 & 0 & 6 & 677 & 963 & 1,477 & 0 & 3 & & & $8 \quad 2017-08-31$ 10:02:54 \\
\hline & KANWLL NUSA TENGGARA BARAT & 886 & 43 & 929 & 140 & 14 & 943 & 1,646 & 78 & 1,724 & 51 & 0 & 51 & 1,775 & 2,718 & 1.269 & 118 & 6 & & & 8 2017-08-31 09:19:14 \\
\hline & KANWZL NUSA TENGGARA TIMUR & 632 & 35 & 667 & 10 & 1 & 668 & 2,367 & 120 & 2,487 & 51 & 0 & 51 & 2.538 & 3,206 & 2.811 & $14^{-}$ & 10 & & 18 & 8 2017-00-31 12:44:24 \\
\hline 23 & KANWIL PAPUA & 427 & 25 & 452 & 70 & 7 & & 1,253 & 49 & 1,302 & 29 & 0 & 29 & 1,331 & 1,790 & 2,267 & & 3 & & & $9 \quad 2017-08-31$ 08:16:48 \\
\hline & KANWIL PAPUA BARAT & 237 & 12 & 249 & 00 & 0 & & 644 & 32 & & 220 & 0 & 22 & & 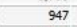 & & & 2 & & & \\
\hline 25 & KANWVLL RIAU & 2.289 & 102 & 2.391 & $49=$ & 51 & 2,442 & 7,381 & 438 & 7,819 & 79 & 6 & 85 & 7,904 & 10,346 & 4,294 & 141 & 14 & & 15 & 52017 \\
\hline 26 & KANWIL SULAWEESI BARAT & 228 & 12 & 240 & 80 & 8 & 248 & 470 & 33 & 503 & 70 & 0 & 7 & 510 & 758 & 902 & 0 & 2 & & & $7 \quad 2017-08-3109: 56: 24$ \\
\hline & KANWIL SULAWESI SELATAN & 2,945 & 243 & 3,188 & $97 \quad 1$ & 98 & 3,286 & 4,975 & 341 & 5,316 & 1793 & 3 & 182 & 5,498 & 8,784 & 5,798 & 52 & 21 & & 24 & $4 \quad 2017-00-31$ 09:24:05 \\
\hline 28 & KANWIL SULAWESI TENGAH & 948 & 56 & 1.004 & 90 & 9 & 1,013 & 1,657 & 95 & 1,752 & 28 & 1 & 29 & 1,781 & 2,794 & 1.609 & 74 & 7 & & 10 & 0 2017-08-31 08:00:22 \\
\hline 29 & KANWIL SULAWESI TENGGARA & 1,056 & 56 & 1,112 & 220 & 22 & 1,134 & 1,258 & 69 & 1,327 & $34 \mathrm{c}$ & 0 & 34 & 1,361 & 2,495 & 1,966 & 27 & 6 & & & $8 \quad 2017-06-31 \quad 08: 00: 19$ \\
\hline 30 & KANWVLL SULAWESI UTARA & 699 & 47 & 746 & $14 \mathrm{C}$ & 14 & 760 & 1,742 & 46 & 1,788 & 390 & 0 & 39 & 1,827 & 2,587 & & 26 & 6 & & 13 & 3 2017-00-31 08:20:54 \\
\hline & KANWIL SUMATERA BAR & 1.039 & 70 & 1,109 & & & & & & & & & & & & & & 16 & & & \\
\hline & KANWIL SUMATERA SELATAN & & 123 & & 63 & 1 & & & 444 & & 233 & & & & & & 82 & 18 & & & : $2017-08-3109: 34: 06$ \\
\hline & KANWIL SUMATERA UTARA & 8,935 & 270 & 9,205 & $88=$ & 290 & 9,295 & 17,753 & 964 & 18,717 & $188=$ & & 190 & 18.507 & 28,202 & 11,029 & 159 & 34 & & 38 & 8 2017-00-31 09:26:27 \\
\hline & & & 3,676 & 8,755 & 94619 & 9965 & 69,720 & 44,226 & 8,568 & 52,794 & 2,39850 & $50 \quad 2,4$ & 4481 & 55,242 & 24,962 & 28,040 & 76 & 372 & & 8504 & \\
\hline
\end{tabular}

Tabel. 1.0 tahun 2017

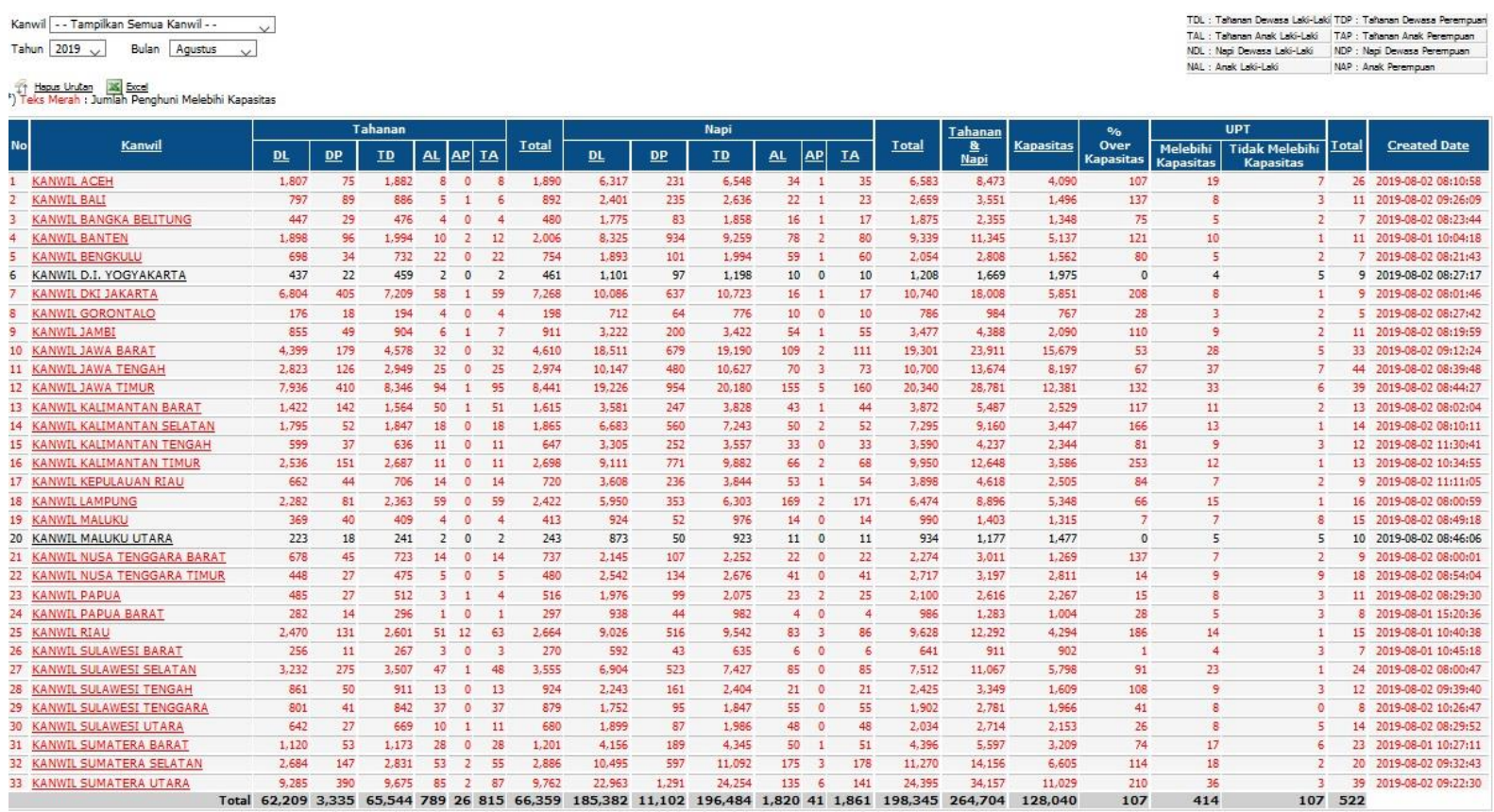

Tabel 1.1 tahun 2018 


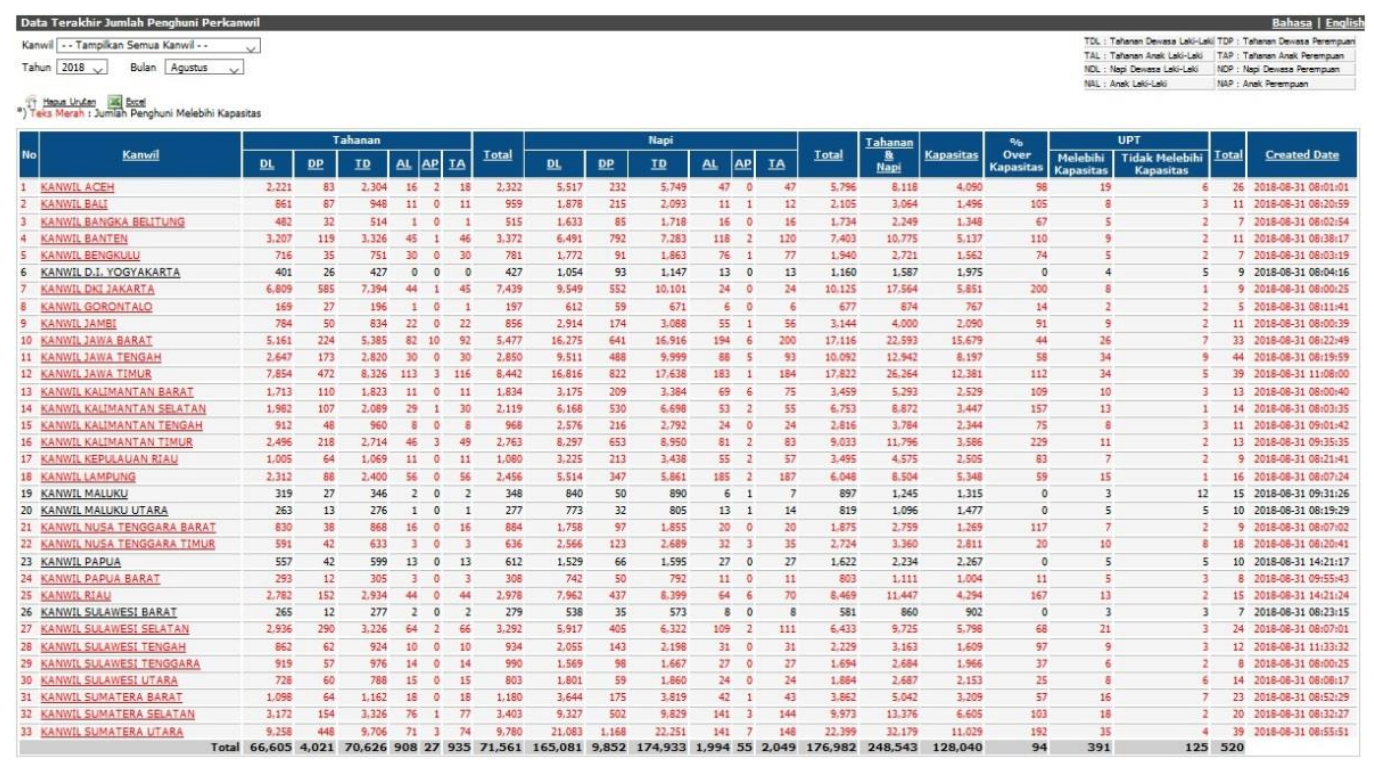

Tabel 1.3 tahun $2019^{6}$

Kemudian lembaga Bantuan Hukum (LBH) Masyarakat kemudian juga mengatakan bahwa, sakit adalah salah satu faktor nomor satu yang menjadi sebab angka kematian tahanan di dalam tahanan serta lapas-lapas di Indonesia sepanjang 2016 dan 2017. Kemudian besarannya sebesar 47,5\% di tahun 2016 dan $60,25 \%$ di tahun 2017. Serta dalam kumulatif besaran jumlah kematian tahanan dan narapidana pada 2016 sebanyak 120 kasus, kemudian pada tahun 2017 sebanyak 83 kasus. Lantas kondisi lapas yang tertutup dan kurangnya sinar matahari juga merupakan faktor yang membuat penyebaran penyakit semakin mudah menyebar, bentuk bangunan yang pengap tanpa ventilasi yang baik serta jumlah narapidana di dalam tahanan yang melebihi batas memperburuk keadaan, salah satu penyakit yang menyebar dalam kondisi seperti ini adalah TBC (Tuberkolosis) ${ }^{7}$. Sementara itu, faktor bunuh diri adalah faktor tertinggi kedua penyebab kematian dilapas, tercatat sekiranya terdapat 43 kejadian bunuh diri dalam kurun waktu 2017-2018 kebelakang. ${ }^{8}$

Lapas yang buruk adalah masalah pelik. Berdasarkan latar belakang yang telah di uraikan maka permasalahan yang akan di kaji adalah bagaimanakah implikasi overcapacity dalam Lembaga pemasyarakatan di Indonesia, dalam penelitian ini akan dilihat apakah faktor overcapacity serta bagaimana dampak nya terhadap Lembaga pemasyarakatan di Indonesia. Dalam penelitian ini penulis memakai metode penelitian kuantitatif dengan mendasarkan dengan metode studi pustaka dalam mengkaji permasalahan di dalam Lembaga pemasyarakatan, serta penulis juga memanfaatkan data statisik dari Badan Pusat Statistik serta berbagai data - data yang turut dapat menunjang penelitian berikut serta menjadi pedoman penelitian. Penulis memanfaatkan pola logika deduktif dalam menarik hasil dari permasalahan yang peneliti teliti, sehingga hasil yang di dapatkan menjadi lebih jelas dan dapat menjawab permasalahan yang ada.

\section{B. Pembahasan}

\section{Kondisi Lembaga Pemasyarakatan di Indonesia}

\footnotetext{
${ }^{6}$ Sistem Database Pemasyarakatan. Data penghuni terakhir perkanwil. Tersedia online pada http://smslap.ditjenpas.go.id/public/grl/current/monthly/year/2019/month/8, di kutip pada tanggal. 02 agustus 2019 pukul 13:49 WIB. ${ }^{7}$ Evrilda Andani Putri, "Faktor Resiko Tuberkolosis Paru Pada Warga Binaan Pemasyarakatan di Lembaga Pemasyarakatan Kelas I Semarang", Jurnal Kesehatan Masyarakat, Vol. 6, No. 1, (2018), hlm. 249.

${ }^{8}$ Dylan Aprialdo Rachman. Kelebihan Kapasitas Dinilai Perparah Tingginya Kematian Penghuni Lapas. Tersedia Online pada https://nasional.kompas.com/read/2018/05/07/12270011/kelebihan-kapasitas-dinilai-perparah-tingginya-kematian-penghuni-lapas, dikutip Pada Tanggal 19 Februari 2019, Pukul 08.37 WIB.
} 
Dirjen Pemasyarakatan Kemenkumham RI, Sri Puguh Budi Utami, mengatakan bahwa jumlah penghuni di lembaga pemasyarakatan dan rumah tahanan saat ini mencapai 55 ribu di Indonesia ${ }^{9}$. Narapidana sebanyak itu menghuni 522 lembaga pemasyarakatan kemudian sebagian besar napi adalah narapidana dengan kasus narkoba. Total narapidana tersebut mencapai jumlah hingga 46.000 yang tertinggi merupakan kasus narkoba hingga 115.000 orang, sejalan dengan banyaknya kasus narkotika yang terjadi. Kemudian juga para narapidana tidak diberikan proses rehabilitasi tapi malah dimasukkan kedalam lapas. Kemudian, di peringkat berikutnya napi terbanyak dalam Lembaga pemasyarakatan dan rumah tahanan merupakan napi tindak pidana kasus pencurian. Kemudian, narapidana tindak pidana teroris dan koruptor turut memenuhi Lembaga pemasyarakatan Indonesia. ${ }^{10}$ Kondisi napi dalam lapas adalah permasalahan serius dalam mewujudkan napi yang baik. Dalam mengelola lapas setidaknya wajib melihat delapan faktor yang menjadi faktor yang memperburuk keadaan lapas seperti yang di utarakan Woolf, antara lain:

a. Kepadatan penjara yang extreme;

b. Kelebihan penghuni;

c. kondisi penjara yang buruk (baik bagi napi serta staff lapas);

d. kurangnya jumlah staff;

e. staf penjara yang saling rusuh;

f. Buruknya sistem keamanan;

g. "Campuran Beracun" dari panjangnya jangka waktu serta penahanan selama seumur serta mental dari tahanan yang terganggu;

h. Kerusuhan diantara para tahanan.

Overcapacity sederhananya dapat disebabkan oleh tingginya jumlah napi yang masuk yang tak berbanding lurus dengan kapasitas Lembaga pemasyarakatan, besaran jumlah napi yang masuk dengan jumlah narapidana yang keluar amat tak berimbang, jumlah narapidana baru jauh melebihi jumlah masa pidana penjaranya dan jumlah narapidana yang keluar lapas ${ }^{11}$. Institute for Criminal and Justice Reform (ICJR) mengatakan bahwa pemangku kekuasaan sudah harus segera memberikan solusi terkait dengan permasalahan overcapacity yang ada. Permasalahan overcapacity telah mencapai kondisi overcapacity yang amat parah, Tercatat pada bulan September tahun 2018, Lembaga pemasyarakatan dan rumah tahanan menampung 248.340 orang. Sedangkan, jumlah ruang yang tersedia hanya dapat menampung 125.159 orang. Besaran jumlah ini kian mengalami kenaikan, lalu pada 2013, jumlah overcapacity menyentuh 143\%. Serta tahun 2017, jumlah tersebut mengalami kenaikan hingga $188 \% .^{12}$

Lantas permasalahan konsumsi bagi para napi turut menjadi permasalahan tersendiri, tahun 2018 biaya ini membesar dan membesar hingga Rp. 1,3 triliun, ${ }^{13}$ lalu tahun 2019 muncul gagasan agar menaikkan biaya tersebut ke angka Rp.1,67 miliar. Apabila di bagi secara merata pada Lembaga pemasyarakatan di 33 provinsi, dengan demikian setiap tahanan mendapat jatah sebesar Rp.15.000 per-hari atau kisaran Rp.5.000 per-sekali makan. Namun mengingat banyak nya jumlah narapidana dan tahanan yang ada maka, satu tahun APBN yang akan dianggarkan dapat menyentuh angka triliunan rupiah. Makan dengan jatah tiga kali dalam satu hari, dengan lauk yang beragam. ${ }^{14}$ Bila disandingkan pada konsumsi tahanan yang berada dalam rumah tahanan Kemenkum HAM, Rumah tahanan KPK terasa lebih dirasa manusiawi karena mendapat jatah makan sebesar Rp.40.000 dalam satu hari. Kemudian dalam Lembaga kepolisan diberikan biaya sebesar Rp.30.000.

9 Jie, Jumlah Penghuni Lapas dan Rutan Terus Meningkat. Tersedia Online pada http://www.rmoljateng.com/read/2019/01/31/16397/Jumlah-Penghuni-Lapas-Dan-Rutan-Terus-Meningkat-, di kutip pada tanggal 05 Mei 2019 pukul 20:17 WIB.

10 Taufik Budi, Jumlah Narapidana Narkoba Rajai Lapas di Indonesia. Tersedia Online pada https://news.okezone.com/read/2019/01/31/512/2012132/jumlah-narapidana-narkoba-rajai-lapas-di-indonesia, di kutip pada tanggal 05 Mei 2019 pukul 20:31 WIB.

${ }^{11}$ Angkasa. "Over Capacity Narapidana di Lembaga Pemasyarakatan, Faktor Penyebab, Implikasi Negatif, Serta Solusi dalam Upaya Optimalisasi Pembinaan Narapidana", Jurnal Dinamika Hukum, Vol. 10 No. 3, (2010), hlm. 214.

12 Devina Halim, ICJR : Rutan dan Lapas di Indonesia Sudah "Extreme Ovecrowding". Tersedia Online pada https://nasional.kompas.com/read/2018/10/17/23242421/icjr-rutan-dan-lapas-di-indonesia-sudah-extreme-overcrowding, dikutip 05 Mei 2019 pada pukul 21:59 WIB.

13 Joko Susilo. Menkumham : lapas sudah terlalu sesak, biaya makan napi triliunan rupiah. Tersedia Online Pada https://www.antaranews.com/berita/701219/menkumham-lapas-sudah-terlalu-sesak-biaya-makan-napi-triliunan-rupiah, di kutip pada tanggal 05 Mei 2019 pada pukul 22:24 WIB.

${ }^{14}$ Andi Saputra. Dijatah APBN Goceng per Makan, Begini Tahanan dan Napi. Tersedia Online pada https://news.detik.com/berita/d3482559/dijatah-apbn-goceng-per-makan-begini-menu-tahanan-dan-napi. di kutip pada tanggal 05 Mei 2019 pada pukul 23:34 Wib 
Kemudian dengan kondisi SDM petugas pemasyarakatan yang ada, maka terlihat bahwa hal ini dapat berpengaruh serta memperlambat proses dari lapas tersebut, selain itu permasalahan overcapacity tentu menjadi penyebab kurang optimalnya pengawasan serta perawatan yang dilakukan oleh petugas lembaga pemasyarakatan dan mengakibatkan tidak tercapainya tujuan dari sistem pemidanaan. Hal ini tak ayal menyebabkan banyak terjadi penyimpangan di dalam lembaga pemasyarakatan ${ }^{15}$. Pemidanaan sejatinya bertujuan demi memperbaiki atau merehabilitasi penjahat menjadi orang yang baik sehingga bermanfaat bagi masyarakat serta mengembalikan sistem keseimbangan, keselarasan dan keserasian di dalam masyarakat. Maka dijatuhkannya hukuman kepada pelaku kejahatan, seharusnya tidak hanya dilihat sebagai suatu balasan atas perbuatan jahat pelaku yang merugikan atau penjeraan semata, namun ada suatu tujuan tertentu yaitu dalam pelaksanaannya hukuman pidana ketika dijatuhkan adalah untuk merehabilitasi perilakunya dan menyatukan kembali narapidana dengan masyarakat ${ }^{16}$. Namun pada kenyataan nya kurangnya peran serta dari masyarakat dalam rangka ikut serta dalam pembinaan narapidana. Hal ini disebabkan oleh kurangnya kepedulian masyarakat terhadap kesejahteraan napi karena sebagian anggota masyarakat masih enggan dan tidak mau menerima kembali bekas napi. Sehingga hal tersebut lah yang menyebabkan belum tercapainya tujuan dari konsep pemidanaan, yaitu untuk memasyarakatkan kembali narapidana ke dalam lingkungan masyarakat. Faktor kurangnya kepedulian dan peran serta masyarakat tersebut lah yang sangat mempengaruhi pencapaian tujuan pemidanaan demi mengintegrasikan kembali para narapidana dengan masyarakat. Kondisi tersebutlah seperti yang terjadi pada Lembaga Pemasyarakatan di kota Magelang, kurangnya partisipasi dari masyarakat Magelang dalam membantu proses pembinaan narapidana, hal ini disebabkan oleh kurangnya kepedulian serta hubungan baik dari lembaga pemasyarakatan dengan masyarakat ${ }^{17}$. Sehingga sejatinya amat diperlukan suatu kerja sama yang baik diantara lembaga pemasyarakatan dan masyarakat demi keberhasilan dalam melakukan pembinaan narapidana.

Kemudian dalam mencapai tujuan pembinaan maka juga harus juga ditunjang dengan pelaksanaan/penerapan hukum yang baik. Menurut Soerjono Soekanto, sebuah tolak ukur dari pada ketidakefektifan hokum, wajib juga memperhatikan faktor- faktor yang juga mempengaruhi efektifitas suatu penerapan hukum tersebut. faktor-faktor tersebut antara lain: ${ }^{18}$

a. Faktor hukum

b. Faktor penegak hukum

c. Faktor sarana atau fasilitas

d. Faktor masyarakat

e. Faktor kebudayaan.

Dengan mempertimbangkan dengan baik kelima faktor-faktor diatas maka dapat di ciptakan sebuah formulasi sebuah kebijakan yang dapat mencakup dan melingkupi berbagai aspek dan elemen yang menyeluruh sehingga dapat di ciptakan sebuah formulasi dari kebijakan dan sistem pemidanaan yang seyogyanya dapat memperbaiki serta merehabilitasi terpidana dengan maksimal serta baik, dengan pemidanaan yang mumpuni kemudian juga di dukung dengan sistem pemidanaan yang mumpuni maka dapatlah di ciptakan sebuah sistem hunian yang dapat memperbaiki para narapidana secara lahir maupun batin, serta kita harus membekali mereka dengan berbagai kemampuan baik soft skill maupun hard skill yang dapat memberikan mereka kemampuan untuk berkerja ketika mereka keluar, serta dapat juga memberikan mereka kesempatan untuk membuka lapangan pekerjaan baru dengan kemampuannya, ketika mereka sudah kembali pada lingkungan masyarakatnya.

\section{Terbatasnya pidana alternatif}

Erasmus Napitupulu, direktur Program ICJR mengatakan bahwa, alternatif pemidanaan sejatinya sudah dikenal lama dalam sistem hukum Indonesia di KUHP, UU Narkotika serta UU Sistem Peradilan Pidana Anak. Namun pada penerapannya masih belum optimal masih banyak kasus yang diputus penjara. Alternatif penjara yang banyak di kenal adalah antara lain pidana kerja sosial, pidana pengawasan, serta pidana dengan

\footnotetext{
${ }^{15}$ Desy Maryani, “Faktor-Faktor Penyebab Tidak Tercapainya Tujuan Pemidanaan Lembaga Pemasyarakatan di Indonesia”, Jurnal Hukum Sehasen, Vol. 1 No. 1, (2015), hlm. 14.

${ }^{16}$ Andi Hamzah, Sistem Pidana dan Pemidanaan dari Retribusi ke Reformasi, Prad Pramita, (1986), hlm. 28.

17 Budi Hermidi, Pembinaan Narapidana Sebagai Upaya Untuk Mewujudkan Tujuan Pemidanaan (Studi Kasus di Lembaga Pemasyarakatan Magelang), Semarang: Universitas Diponegoro, (2001), hlm. 20.

${ }^{18}$ Seorjono Soekanto, Faktor-Faktor yang Mempengaruhi Penegakan Hukum, Jakarta: Raja Grafindo Persada, (2007), hlm. 05.
} 
cara mengangsur ${ }^{19}$. Kemudian Erasmus mengatakan bahwa, sudah semestinya pemerintah bersama DPR mengoptimalkan konsep pemidanaan alternatif sebagai solusi dalam mengatasi permasalahan overkapasitas penjara yang kian menjadi masalah pelik. Pidana alternative ini belum dapat di terapkan secara maksimal meski kita telah memiliki beberapa pidana alternative yang pada kenyatanya penegak hukum justru lebih memilih untuk menjatuhkan pidana penjara sebagai putusan untuk segala jenis tindak pidana. Asas Restorative Justice seharusnya yang harus menjadi dasar dari sistem pemidanaan dan hukum di Indonesia, asas kekeluargaan serta penyelesaian sengketa dengan konsep di luar pengadilan ini masih menjadi hal yang langka dalam proses hukum kita. Sehingga salah satu pidana alternative yang seharusnya di terapkan di Indonesia adalah pidana kerja sosial dengan konsep yang menekankan sistem yang humanisasi, dengan sistem pelayanan masyarakat yang demikian pelaku dapat segera kembali diterima di dalam masyarakat, dengan memasukkan pelaku kedalam penjara justru dapat memberikan stigma buruk khususnya bagi pelaku anak-anak, dengan stigma dan label buruk bagi pelaku anak dibawah umur justru dapat membentuk pribadi seorang anak menjadi seorang dengan kepribadian buruk di kemudian hari.

Sistem pemidanaan Indonesia saat ini dibentuk demi melindungi kepentingan seorang individu dan hak asasi manusianya serta melindungi kepentingan masyarakat luas, serta juga melindungi negara dari perbuatan jahat serta dari berbagai perbuatan tercela yang merugikan masyarakat, negara, serta individu, dan juga menjaga agar para penguasa tidak berlaku dan bertindak secara sewenang-wenang kepada para masyarakat. Sudah dapat terlihat bahwa apabila ketika masyarakat ingin menuntut keadilan melalui jalur proses hukum pidana akan menghadapi kendala, yaitu hukum hukum pidana formil, filsafat hukum pidana, dan pemidanaan yang ada memang tidak dirancang secara langsung untuk merespon dampak kejahatan terhadap korban dan masyarakat atau problem sosial kemanusiaan yang menyertainya. ${ }^{20}$

\section{Penutup}

Perbaikan sistem pemasyarakatan menjadi suatu hal wajib dan mendasar dalam sistem pemidanaan kita, kurangnya perhatian terhadap para narapidana justru membuat kondisi narapidana semakin memburuk, stigma negatif bagi mereka sebagai "penyakit masyarakat" yang harus disingkirkan membuat segala permasalahan yang meliputi sistem pemasyarakatan kita semakin berlarut-larut. ke Pemerintah harus mengambil sebuah langkah konkret untuk membimbing para narapidana keluar dari stigma negatif dan kembali ke dalam lingkungan masyarakat, pemerintah memiliki tanggung jawab besar untuk mengembalikan mereka kembali ke masyarakat dan menyeleksi siapa saja yang dapat di masukkan kedalam penjara, penjara tidak dapat lagi menjadi pembuangan akhir bagi orang-orang yang melakukan tindak pidana.

Pelaku harus di berikan pembinaan mendalam dan penguatan finansial dan kemampuan untuk bekerja sehingga pelaku tidak kembali menjadi residivis, asas restorative justice juga merupakan kunci penting dalam pembinaan narapidana, penegak hukum harus bertindak sebagai pihak yang menengahi kedua pihak baik melindungi pelaku dan mengadili pelaku seadil-adilnya, kurangnya pilihan pemidanaan juga menjadi masalah yang harus di perbaiki penegak hukum mudahnya menggunakan penjara sebagai pilihan utama dan bukan ultimum remedium membuat para pelaku kian menumpuk di dalam penjara, dengan adanya pilihan pemidanaan lain membuat narapidana khususnya untuk pidana di bawah 6-5 tahun dapat di berikan pidana non-pemenjaraan sehingga mereka dapat mengabdi kepada masyarakat dan memanfaatkan waktunya dengan membaur dengan masyarakat yang telah ia "ciderai".

\section{DAFTAR PUSTAKA}

\section{A. Buku}

Departemen Kehakiman R1. (1983). Dari Kepenjaraan Kepemasyarakatan, Direktorat Jendral Pemasyarakatan. Jakarta: Departemen Kehakiman Rl.

Panjaitan, Petrusirawan. (2007). Pidana Penjara Mau Kemana. Jakarta: Ind-hill CO.

Atmasasmita, Romli. Dari Pemendjaraan ke Pembinaan Narapidana. Bandung: Alumni. Hamzah, Andi. (1986). Sistem Pidana dan Pemidanaan dari Retribusi ke Reformasi. Prad Pramita.

\footnotetext{
19 Erwin C Sihombing. Penjara Penuh, Hukuman Pidana Non-Penjara Jadi Alternatif. Tersedia Online pada https://www.beritasatu.com/nasional/540327/penjara-penuh-hukuman-pidana-nonpenjara-jadi-alternatif, di kutip pada tanggal 05 agustus 2019 pukul 09:43 WIB.

${ }^{20}$ Muhammad Fajar Septianto, Pidana Kerja Sosial Sebagai Alternatif Pidana Penjara Jangka Pendek, Malang: Fakultas Hukum Universitas Brawijaya, (2014), hlm. 15.
} 
Hermidi, Budi. (2001). Pembinaan Narapidana Sebagai Upaya Untuk Mewujudkan Tujuan Pemidanaan (Studi Kasus di Lembaga Pemasyarakatan Magelang). Semarang: Universitas Diponegoro.

Soekanto, Seorjono. (2007). Faktor-Faktor yang Mempengaruhi Penegakan Hukum. Jakarta: Raja Grafindo Persada.

Muhammad Fajar Septianto, Pidana Kerja Sosial Sebagai Alternatif Pidana Penjara Jangka Pendek, Malang: Fakultas Hukum Universitas Brawijaya, (2014)

\section{B. Jurnal}

Angkasa. "Over Capacity Narapidana di Lembaga Pemasyarakatan, Faktor Penyebab, Implikasi Negatif, Serta Solusi dalam Upaya Optimalisasi Pembinaan Narapidana”, Jurnal Dinamika Hukum, Vol. 10 No. 3, (2010).

Desy Maryani, "Faktor-Faktor Penyebab Tidak Tercapainya Tujuan Pemidanaan Lembaga Pemasyarakatan di Indonesia", Jurnal Hukum Sehasen, Vol. 1 No. 1, (2015).

Evrilda Andani Putri, "Faktor Resiko Tuberkolosis Paru Pada Warga Binaan Pemasyarakatan di Lembaga Pemasyarakatan Kelas I Semarang", Jurnal Kesehatan Masyarakat, Vol. 6, No. 1, (2018).

\section{Internet}

Hendaru Tri Hanggoro. Cerita Dari balik Jeruji Besi. Tersedia Online di https://historia.id/politik/articles/cerita-dari-balik-jeruji-besi-vqjAB, dikutip pada tanggal 05 Mei 2019 pada pukul 23:41 WIB

Mihardi. Ditjen Pas Ungkap Empat Penyebab Lapas Kelebihan Kapasitas. Tersedia Onile pada https://nasional.sindonews.com/read/1161936/13/ditjen-pas-ungkap-empat-penyebab-lapas-kelebihankapasitas-1481310610, dikutip pada Tanggal 19 Februari 2019, Pukul 08.32 WIB.

Sistem Database Pemasyarakatan. Data penghuni terakhir perkanwil. Tersedia online pada http://smslap.ditjenpas.go.id/public/grl/current/monthly/year/2019/month/8, di kutip pada tanggal. 02 agustus 2019 pukul 13:49 Wib

Dylan Aprialdo Rachman. Kelebihan Kapasitas Dinilai Perparah Tingginya Kematian Penghuni Lapas. Tersedia Online pada https://nasional.kompas.com/read/2018/05/07/12270011/kelebihan-kapasitasdinilai-perparah-tingginya-kematian-penghuni-lapas, dikutip Pada Tanggal 19 Februari 2019, Pukul 08.37 WIB

Jie, Jumlah Penghuni Lapas dan Rutan Terus Meningkat. Tersedia Online pada http://www.rmoljateng.com/read/2019/01/31/16397/Jumlah-Penghuni-Lapas-Dan-Rutan-TerusMeningkat-, di kutip pada tanggal 05 Mei 2019 pukul 20:17 Wib

Taufik Budi, Jumlah Narapidana Narkoba Rajai Lapas di Indonesia. Tersedia Online pada https://news.okezone.com/read/2019/01/31/512/2012132/jumlah-narapidana-narkoba-rajai-lapas-diindonesia, di kutip pada tanggal 05 Mei 2019 pukul 20:31 WIB

Devina Halim, ICJR : Rutan dan Lapas di Indonesia Sudah "Extreme Ovecrowding”. Tersedia Online pada https://nasional.kompas.com/read/2018/10/17/23242421/icjr-rutan-dan-lapas-di-indonesia-sudahextreme-overcrowding, dikutip 05 Mei 2019 pada pukul 21:59 WIB

Joko Susilo. Menkumham : lapas sudah terlalu sesak, biaya makan napi triliunan rupiah. Tersedia Online Pada https://www.antaranews.com/berita/701219/menkumham-lapas-sudah-terlalu-sesak-biayamakan-napi-triliunan-rupiah, di kutip pada tanggal 05 Mei 2019 pada pukul 22:24 WIB

Andi Saputra. Dijatah APBN Goceng per Makan, Begini Tahanan dan Napi. Tersedia Online pada https://news.detik.com/berita/d-3482559/dijatah-apbn-goceng-per-makan-begini-menu-tahanan-dannapi. di kutip pada tanggal 05 Mei 2019 pada pukul 23:34 WIB

Erwin C Sihombing. Penjara Penuh, Hukuman Pidana Non-Penjara Jadi Alternatif. Tersedia Online pada https://www.beritasatu.com/nasional/540327/penjara-penuh-hukuman-pidana-nonpenjara-jadialternatif, di kutip pada tanggal 05 agustus 2019 pukul 09:43 WIB 